\title{
Detergent Dissociation of Bovine Liver Phosphomannosyl Binding Protein
}

\author{
Diane C. Mitchell, Thomas Maler, and George W. Jourdian \\ Departments of Biological Chemistry and Internal Medicine (G.W.J.), and Rackham Arthritis \\ Research Unit (D.C.M., T.M., G.W.d.), University of Michigan School of Medicine, Ann Arbor, \\ Michigan 48109
}

We have reported previously the isolation and partial characterization of a 215 kilodalton (Kd) phosphomannosyl binding protein from bovine liver membranes $[3,9]$. In the present studies evidence is presented that the binding protein is an aggregate. Four $\mathrm{N}$-terminal amino acids were detected, and the complex could be dissociated into subunits.

Bovine liver membranes were extracted with the detergent, Zwittergent, in the presence of protease inhibitors. The extract was subjected to affinity chromatography on phosphomannan-Sepharose 4B, and proteins with apparent $M_{\mathrm{r}}$ values of 215 and $57 \mathrm{Kd}$ were eluted with mannose 6-phosphate. As reported previously, extraction with Triton X-100 yielded only the higher molecular weight material. When the binding protein was incubated at $4^{\circ} \mathrm{C}$ in the presence of Zwittergent TM 3-14 the 215-Kd form slowly dissociated into smaller subunits; after two months, the major species had an apparent $M_{\mathrm{r}}$ of $57 \mathrm{Kd}$. The subunits derived from the binding protein were recognized by antiserum raised against purified binding protein. Dissociation of the binding protein by $\mathrm{Zwittergent}$ was enhanced by incubation at $37^{\circ} \mathrm{C}$, the presence of dithiothreitol, and low pH values. The subunit mixture enriched in the 57-Kd subunit had a lowered ability to bind ligands containing the phosphomannosyl recognition marker. Binding was partially restored ( $>48 \%$ of the initial value) when dissociated receptor was back exchanged with Triton $\mathrm{X}-100$.

Key words: phosphomannosyl receptor, detergent dissociation, mannose 6-phosphate

Previous studies have identified a protein present in bovine liver that binds lysosomal enzymes containing high-mannose-type oligosaccharides bearing covalently attached mannose 6-phosphate (Man 6-P) residues. Present evidence suggests that this phosphomannosyl binding protein (PMR) is involved in the uptake of extracellular lysosomal enzymes by cells and the intracellular transport of newly synthesized enzymes to lysosomes [1-8]. the receptor was demonstrated both on the cell surface and in the interior of human diploid fibroblasts $[1,2]$ and has been found in a wide variety of other mammalian cells including rat hepatocytes [3], Chinese hamster ovary cells $[3,4]$, swarm rat chondrosarcoma membranes [5], human [6] and mouse cell lines [7], and a number of rat tissues [8]. The binding protein, isolated initially from ${ }^{125}$ I-labeled bovine plasma membranes [3], has been subsequently 
prepared from bovine liver [9], rat spleen [10], and swarm rat chondrosarcoma membranes [5]. Each PMR preparation when prepared with Triton X-100 and purified on affinity matrices containing covalently linked $\beta$-galactosidase [3], phosphomannan [9], or Dictostylium discoideum (D discoideum) secretions [11,12] exhibited an apparent $M_{\mathrm{r}}$ of $215 \mathrm{Kd}$ on SDS-polyacrylamide gel electrophoresis (SDS-PAGE) conducted under reducing conditions.

The extraordinarily high molecular weight of the bovine liver binding protein and the observation that other receptors associated with the cell surface consist of subunits [13] prompted studies to establish if the bovine liver phosphomannosyl binding protein might be an aggregate of tightly associated protein units. More recently, PMR isolated from lysosome-enriched monkey brain preparations has been shown to exhibit multiple protein-staining bands on SDS-PAGE [14]. This manuscript presents evidence (1) that homogenious, affinity-purified binding protein can be dissociated in the presence of a zwitterionic detergent, (2) that dissociated binding protein exhibits a marked decrease in its ability to bind oligosaccharide chains containing Man 6-P residues, and (3) that incubation of subunits in the presence of Triton $\mathrm{X}-100$ restores binding activity.

\section{MATERIALS AND METHODS}

Mannose 6-phosphate, methyl- $\alpha$-mannoside, concanavalin $\mathrm{A}$, protein $\mathrm{A}$, and Triton X-100 were obtained from Sigma. All polyacrylamide electrophoresis reagents and supplies including high and low molecular weight standards were obtained from BioRad. Zwittergent TM 3-14 (N-tetradecyl-N,N-dimethyl-3-ammonio-1-propanesulfonate, hereafter called $Z$ wittergent) was obtained from Calbiochem-Behring. Nitrocellulose paper BA85 $(0.45 \mu \mathrm{m})$ was obtained from Schleicher and Schuell.

Phosphomannosyl binding protein was isolated from fresh bovine liver as previously described [9] and stored in the presence of $5 \mathrm{mM}$ Man 6-P. When Triton X-100 contained in PMR preparations was exchanged with Zwittergent, PMR was adsorbed on a phosphomannan-Sepharose 4B affinity matrix, the column was washed and eluted as described in the preparation of PMR except $0.04 \%(\mathrm{w} / \mathrm{v}) \mathrm{Zwittergent}$ replaced Triton $X-100$ in the solutions. The binding protein PMR was labeled with

${ }^{125} \mathrm{I}(21 \mathrm{mCi} / \mu$ atom I, Amersham) in the presence of Iodo-beads as described by the manufacturer (Pierce). The labeled product was resolved from unreacted ${ }^{125} \mathrm{I}$ by gel filtration on PD 10 columns (Pharmacia); the labeled product eluted in the void volume of the column. The [ $\left.{ }^{125} \mathrm{I}\right] \mathrm{PMR}$ was further purified by adsorption to, and elution from, a column of phosphomannan-Sepharose 4B. In some experiments a proteinase inhibitor cocktail consisting of $0.1 \mathrm{M} 6$ aminohexanoic acid, $10 \mathrm{mM}$ EDTA, $1 \mathrm{mM}$ benzamidine- $\mathrm{HCl}$, and $10 \mathrm{mM}$-ethylmaleimide (final concentrations), was included in the solutions during the isolation of PMR. The PMR was quantitated either by a binding assay in which $\beta$-galactosidase activity appearing in an immunoprecipitated enzyme-PMR complex was measured [9], by a radioimmunoassay procedure [15], or by measurement of $\left[{ }^{125}\right.$ I]PMR precipitated with anti-PMR in the presence of IgGsorb (Enzyme Center, Inc). Antisera against bovine PMR [9] was prepared as previously described. Protein was determined by a modification of the Lowry procedure [16] or with a Coomassie blue reagent (BioRad).

Polyacrylamide gel electrophoresis was carried out in the presence of SDS on slab gels by the method of Laemmli [17] in the presence of mercaptoethanol unless 
otherwise specified. The concentrations of acrylamide varied between $7.5 \%$ and $10 \%$ and are specified in the text. Unlabeled proteins were detected with a Coomassie blue stain or a silver nitrate reagent [18]. Radioactivity was detected on dried gels by autoradiography using Kodak X-Omat AR film in holders equipped with Cronex highspeed intensifying screens (Dupont). In some experiments PMR and derived components were transferred from polyacrylamide slab gels to nitrocellulose paper (Schleicher and Schuell) by an immunoblotting procedure. The binding protein was detected by autoradiography after sequential treatment of the blot with antiserum against PMR and [ ${ }^{125}$ I]protein A [19].

The N-terminal and amino acid analyses were performed on PMR freed of Triton $\mathrm{X}-100$ by exhaustive dialysis at $4^{\circ} \mathrm{C}$ against $15 \%$ ethanol. The $\mathrm{N}$-terminal amino acid content was determined by the procedure of Tarr [20]; amino acids that were released were determined as their phenylthiohydantoin derivatives by highperformance liquid chromatography (HPLC). Amino acid analyses were performed on a Beckman model $121 \mathrm{M}$ amino acid analyzer after hydrolysis at $110^{\circ} \mathrm{C}$ in $6 \mathrm{~N}$ $\mathrm{HCl}$ for $24 \mathrm{hr}$ [21]. Proteinase activity was determined by the procedure of Williams and Lin [22]; [ ${ }^{14} \mathrm{C}$-methyl]methylated methemoglobin $(0.017 \mathrm{mCi} / \mathrm{mg}$, New England Nuclear) served as substrate.

\section{RESULTS}

Previous studies have shown that PMR, extracted with Triton X-100 and stored in Man 6-P, migrates on SDS-PAGE slab gels as a single component with an apparent $M_{\mathrm{r}}$ of $215 \mathrm{Kd}$ [3]. Occasionally, particularly on long storage in the absence of Man 6$P$, lower molecular weight forms have been observed. A number of other detergents were used to extract PMR, and of these Zwittergent offered considerable promise in terms of increased yields and ease of removal of the detergent [15]. However, a new component with an aparent $M_{\mathrm{r}}$ of $57 \mathrm{Kd}$ was detected when Zwittergent-extracted PMR was subjected to SDS-PAGE (Fig. 1). Both the Triton X-100 and Zwittergentextracted PMR preparations exhibited a major band with an apparent $M_{\mathrm{r}}$ of $215 \mathrm{Kd}$ but only the Zwittergent-extracted PMR preparation contained the 57-Kd component. The relative amount of the lower molecular weight component varied from preparation to preparation.

Affinity-purified PMR, freed of detergent, was analyzed for its amino acid content. As is the case with other integral membrane proteins, PMR contains elevated levels of acidic and hydrophobic amino acid residues (Table I). That PMR is an aggregate comprising more than one protein was suggested by the results of $\mathrm{N}$ terminal amino acid analyses. Four $\mathrm{N}$-terminal amino acid residues were detectedserine, glycine, tyrosine, and glutamic acid (Table I). These results support the concept that PMR is composed of subunits.

That the subunits are tightly associated is suggested by the following results. Incubation of PMR in $1 \%$ SDS or $4 \mathrm{M}$ urea at $48^{\circ} \mathrm{C}$ for $24 \mathrm{hr}$ did not alter the observed $M_{\mathrm{r}}$ of PMR (data not shown). However, when $\left[{ }^{125} \mathrm{I}\right] \mathrm{PMR}$ was incubated at $37^{\circ} \mathrm{C}$ with Zwittergent and dithiothreitol at $\mathrm{pH} 4.5$ and 6.2 , lower molecular weight forms appeared on SDS-PAGE (Fig. 2). In contrast, when [ ${ }^{125}$ I]PMR was incubated at $\mathrm{pH} 7.9$, the $M_{\mathrm{r}}$ increased and most of the PMR did not penetrate the gel. Both the dissociation at low $\mathrm{pH}$ values and apparent aggregation at the higher $\mathrm{pH}$ values were enhanced with increasing concentrations of reducing agent. 


\section{Detergent}

\section{Zwittergent Triton $\mathrm{X}-100$ Std}

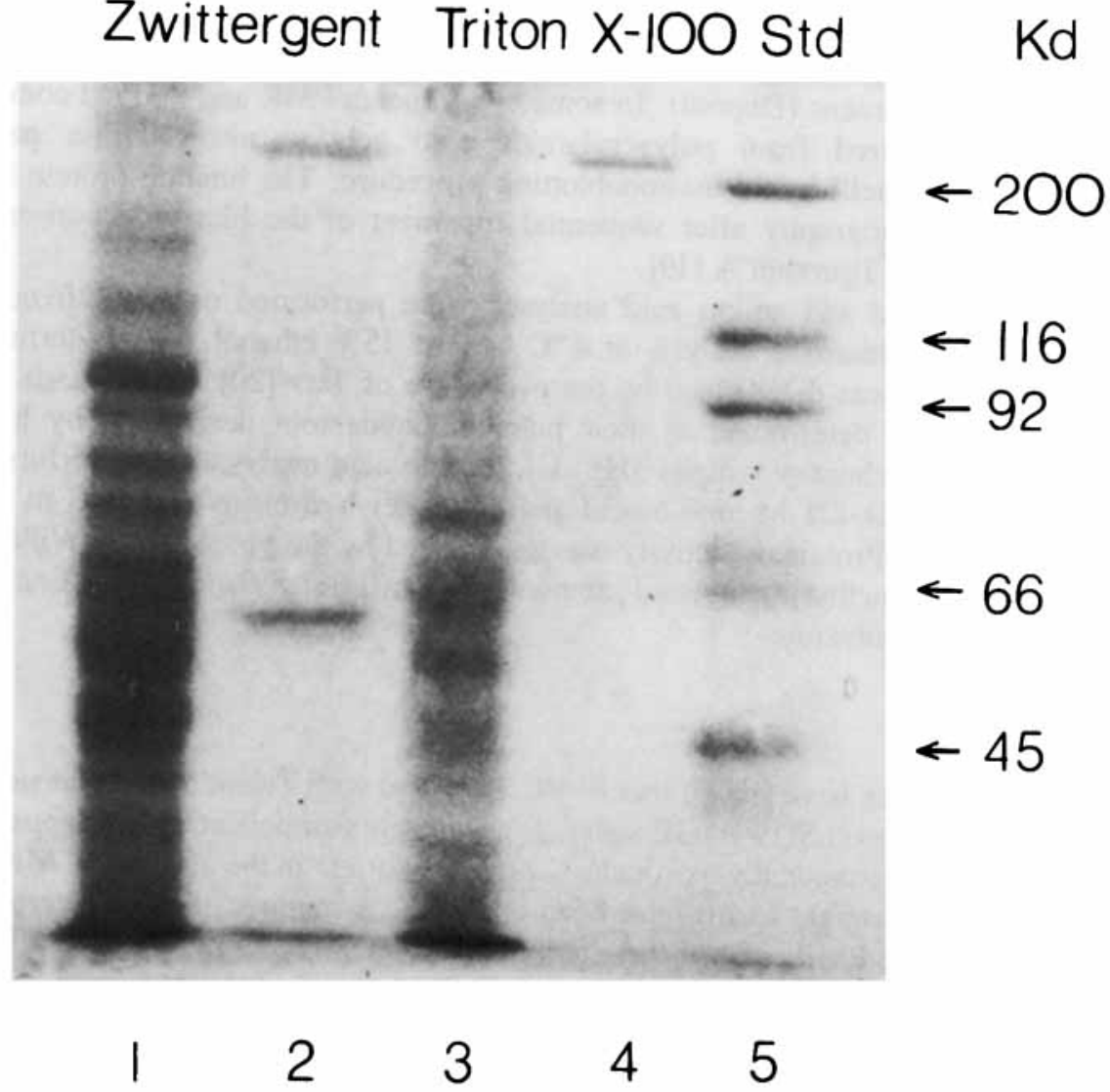

Fig. 1. Effect of Zwittergent on the SDS-PAGE profiles of PMR from bovine liver membranes. Membrane proteins were extracted with $1 \%$ Triton X-100 or $1 \%$ Zwittergent as previously described [15]. Equivalent amounts of each "solubilized" protein mixture were applied to duplicate affinity columns containing phosphomannan-Sepharose $4 \mathrm{~B}$. The respective columns were equilibrated, washed, and eluted with solutions containing either $0.05 \%$ Triton X-100 or $0.02 \%$ Zwittergent. Lanes 1 and 2 show the affinity column wash and $5 \mathrm{mM}$ Man 6-P eluant, respectively, of the Zwittergent-extracted proteins; lanes 3 and 4 show the affinity column wash and $5 \mathrm{mM}$ Man 6-P eluant of the Triton X-100extracted proteins, respectively; lane 5 contained a mixture of protein standards with the indicated $M_{\mathrm{r}}$ values. Gels $(7.5 \%)$ were stained with Coomassie blue.

Zwittergent was not essential for production of multiple bands from PMR. Triton X-100-prepared PMR when stored at $4{ }^{\circ} \mathrm{C}$ for long periods (6 months) in the absence of Man 6-P also exhibited multiple components, including one with an apparent $M_{\mathrm{r}}$ of $57 \mathrm{Kd}$ (Fig. 3); multiple bands were not observed in preparations stored at $4^{\circ} \mathrm{C}$ in $5 \mathrm{mM}$ Man 6-P.

Similar results were obtained when PMR, labeled with ${ }^{125} \mathrm{I}$ and exchanged with Zwittergent, was incubated at $4{ }^{\circ} \mathrm{C}$ for various times (Fig. 4). the Zwittergentexchanged $\left[{ }^{125}\right.$ I]PMR showed multiple components on autoradiograms even in the 
Table I. Amino Acid Composition of Bovine Liver PMR*

\begin{tabular}{|c|c|c|}
\hline \multirow[b]{2}{*}{ Amino acids } & \multicolumn{2}{|c|}{ Preparation } \\
\hline & 1 & 2 \\
\hline \multicolumn{3}{|c|}{ Total (residues $/ 1,000$ ) } \\
\hline Lysine & 73 & 64 \\
\hline Histidine & 21 & 20 \\
\hline Arginine & 49 & 51 \\
\hline Aspartic acid & 110 & 109 \\
\hline Threonine & 67 & 74 \\
\hline Serine & 85 & 92 \\
\hline Glutamic acid & 104 & 96 \\
\hline Proline & 50 & 53 \\
\hline Glycine & 86 & 89 \\
\hline Alanine & 73 & 67 \\
\hline Half cystine & 30 & 34 \\
\hline Valine & 65 & 62 \\
\hline Methionine & $<2$ & $<2$ \\
\hline Isoleucine & 26 & 26 \\
\hline Leucine & 86 & 82 \\
\hline Tyrosine & 34 & 38 \\
\hline Phenylalanine & 39 & 40 \\
\hline Tryptophan & $\mathrm{ND}^{\mathrm{a}}$ & $\mathrm{ND}^{\mathrm{a}}$ \\
\hline \multicolumn{3}{|c|}{$\mathrm{N}$-Terminal (molar ratio) } \\
\hline Serine & 1.5 & \\
\hline Glycine & 1.1 & \\
\hline Tyrosine & 1.0 & \\
\hline Glutamic acid & 2.1 & \\
\hline
\end{tabular}

*Two separate Triton X-100-extracted PMR preparations were freed of detergent and salts by exhaustive dialysis at $4^{\circ} \mathrm{C}$ against $15 \%$ ethyl alcohol prior to determination of amino acid content as described in Methods.

${ }^{\mathrm{a}} \mathrm{ND}=$ not determined.

presence of $5 \mathrm{mM}$ Man 6-P within 14 days. After 56 days the major component had an apparent $M_{\mathrm{r}}$ of $57 \mathrm{Kd}$. Similar multiple bands were detected in an unlabeled Zwittergent-exchanged PMR preparation held at $4^{\circ} \mathrm{C}$ for 2 weeks and then sequentially subjected to SDS-PAGE and an immunoblotting procedure (Fig. 5). The similarity of the protein profiles obtained with each method suggests that iodination neither alters the dissociation nor the immunological properties of PMR.

The profile of bands observed in Figure 5A (antiserum against affinity purified, PMR) and those observed in Figure 5B (antiserum against PMR; the PMR was sequentially purified by affinity chromatography and SDS-PAGE and had an apparent $M_{\mathrm{r}}$ of $215 \mathrm{Kd}$ ) were similar. These results suggest that the antiserum raised against affinity-purified PMR contains only antibodies that specifically recognize PMR.

While the above information supports the hypothesis that PMR is composed of an aggregate of self-associated proteins or subunits, the possibility of enzymatic fragmentation could not be dismissed. In an attempt to rule out the action of proteolytic enzymes the following studies were conducted. Binding protein was extracted with Zwittergent in the presence and absence of the proteinase inhibitor cocktail described in Methods. The SDS-PAGE profiles obtained were nearly identical (data 


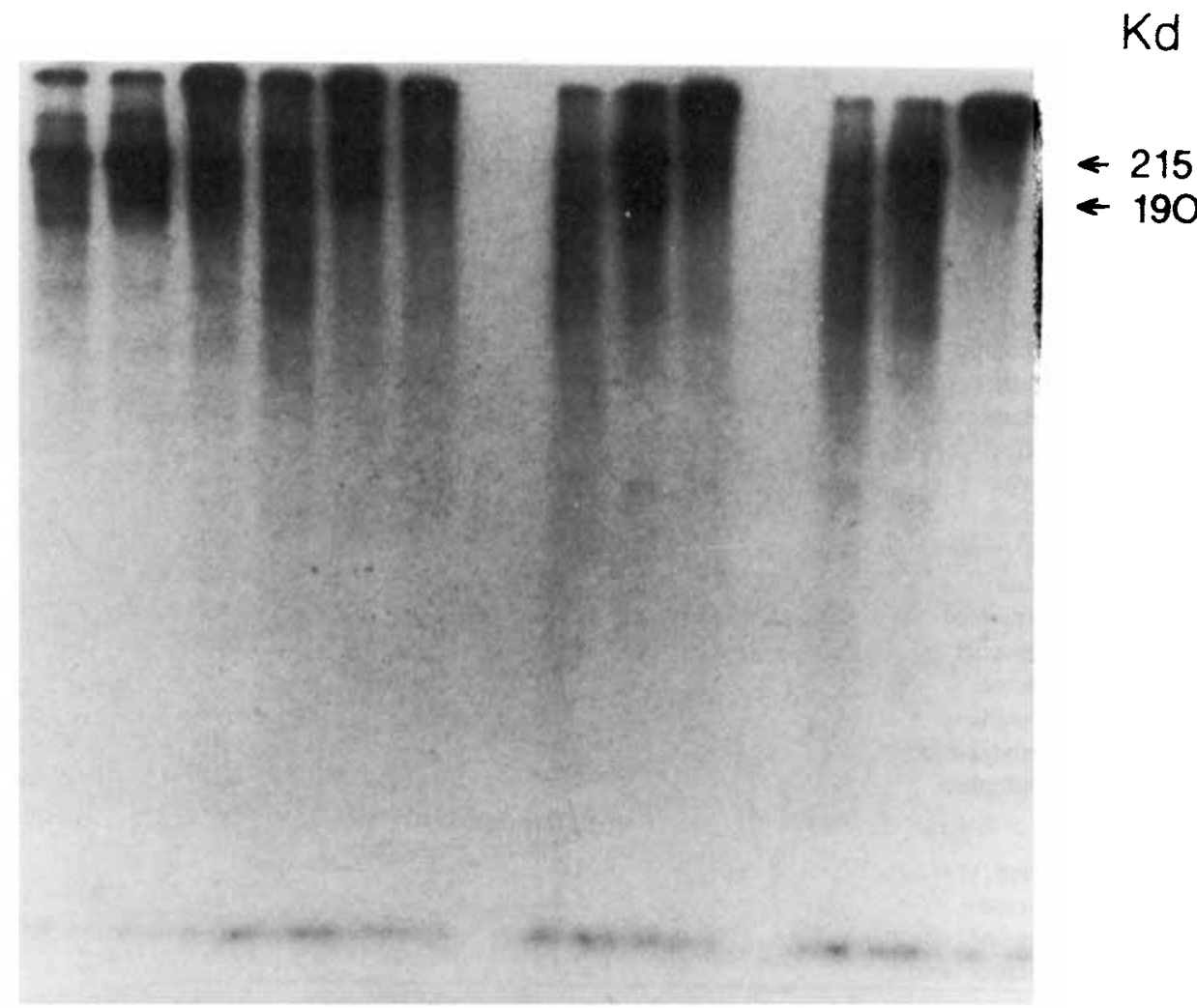

\section{$\begin{array}{llllllllllll}1 & 2 & 3 & 4 & 5 & 6 & 7 & 8 & 9 & 10 & 11 & 12\end{array}$}

Fig. 2. Effect of $\mathrm{pH}$ and dithiothreitol on SDS-PAGE profiles of ${ }^{125} \mathrm{I}-\mathrm{PMR}$ stored in Zwittergent. The binding protein ( ${ }^{125}$ I-PMR) was prepared and exchanged with Zwittergent as described in Methods. Aliquots were dialyzed against citrate-phosphate buffer solutions adjusted to pH values of 4.5, 6.2, and 7.9 , respectively; each solution contained $0.15 \mathrm{M} \mathrm{NaCl}, 0.04 \%$ Zwittergent, and $0.02 \%$ sodium azide. Varying concentrations of dithiothreitol were added to the reaction mixtures described below. After incubation at $37^{\circ} \mathrm{C}$ for $36 \mathrm{hr}$, aliquots were subjected to SDS-PAGE using a $10 \%$ gel; ${ }^{125}$ I-proteins were detected by autoradiography. In lanes $1,4,7$, and 10, PMR was incubated at pH 4.5 in the presence of dithiothreitol at final concentrations of $0,1.0,10$, and $50 \mathrm{mM}$, respectively; in lanes $2,5,8$, and 11 , PMR was incubated at $\mathrm{pH} 6.2$ at the concentrations of dithiothreitol corresponding to those described above; and in lanes $3,6,9$, and 12, PMR was incubated at $\mathrm{pH} 7.9$ with the same increasing concentrations of dithiothreitol.

not shown). In other experiments ${ }^{14} \mathrm{C}$-methyl methemoglobin was incorporated into incubation mixtures containing PMR to detect proteinases. The mixtures were assayed for trichloroacetic acid-soluble fragments [22]. Several PMR samples prepared with Zwittergent or Triton $\mathrm{X}-100$, and incubated under varying conditions, were examined for their ability to degrade the ${ }^{14} \mathrm{C}$-labeled substrate (Table II). Varying levels of proteolytic activity were detected in all preparations, including those incubated in the presence of the inhibitor cocktail. However, the extensive dissociation of PMR observed in the Zwittergent-stored preparation could not be ascribed to the level of 


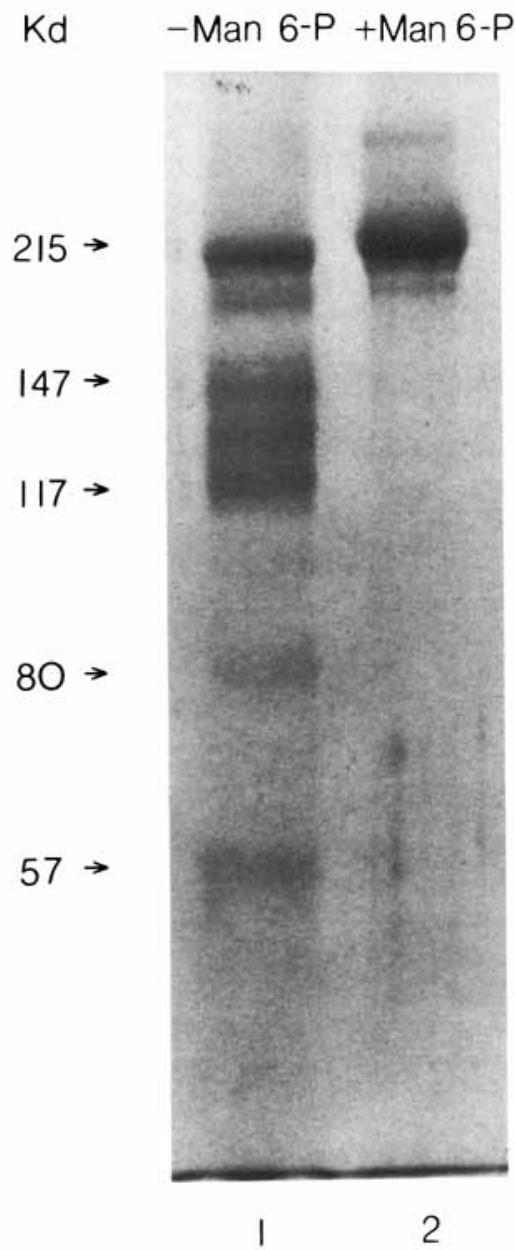

Fig. 3. Effect of storage of PMR in Man 6-P. Binding protein was extracted in the presence of Triton $\mathrm{X}-100$, purified by affinity chromatography and stored at $-19^{\circ} \mathrm{C}$ for 6 months in the absence (lane 1 ) or presence (lane 2) of $5 \mathrm{mM}$ Man 6-P. SDS-PAGE was performed on a $7.5 \%$ gel. The apparent $M_{\mathrm{I}}$ values of undissociated PMR and dissociated subunits of PMR are shown.

proteolytic activity in this preparation. In addition, proteolytic activity was not significantly enhanced at lower $\mathrm{pH}$ values where increased dissociation was observed. An unusually high level of proteolytic activity was found in the PMR preparation stored in the absence of Man 6-P; addition of Man 6-P did not lower proteolytic activity of the preparation (Table II). Furthermore, the SDS-PAGE profiles of the PMR preparations before and after incubation, in the presence or absence of proteinase inhibitor cocktail, remained the same. We conclude from these results that PMR preparations contain variable levels of proteolytic activity, and that the proteolytic activity bears no relationship to receptor dissociation or the presence of proteinase inhibitors. Whether the observed proteolytic activity is a constitutive property of PMR or represents a contaminating proteinase remains to be established. 

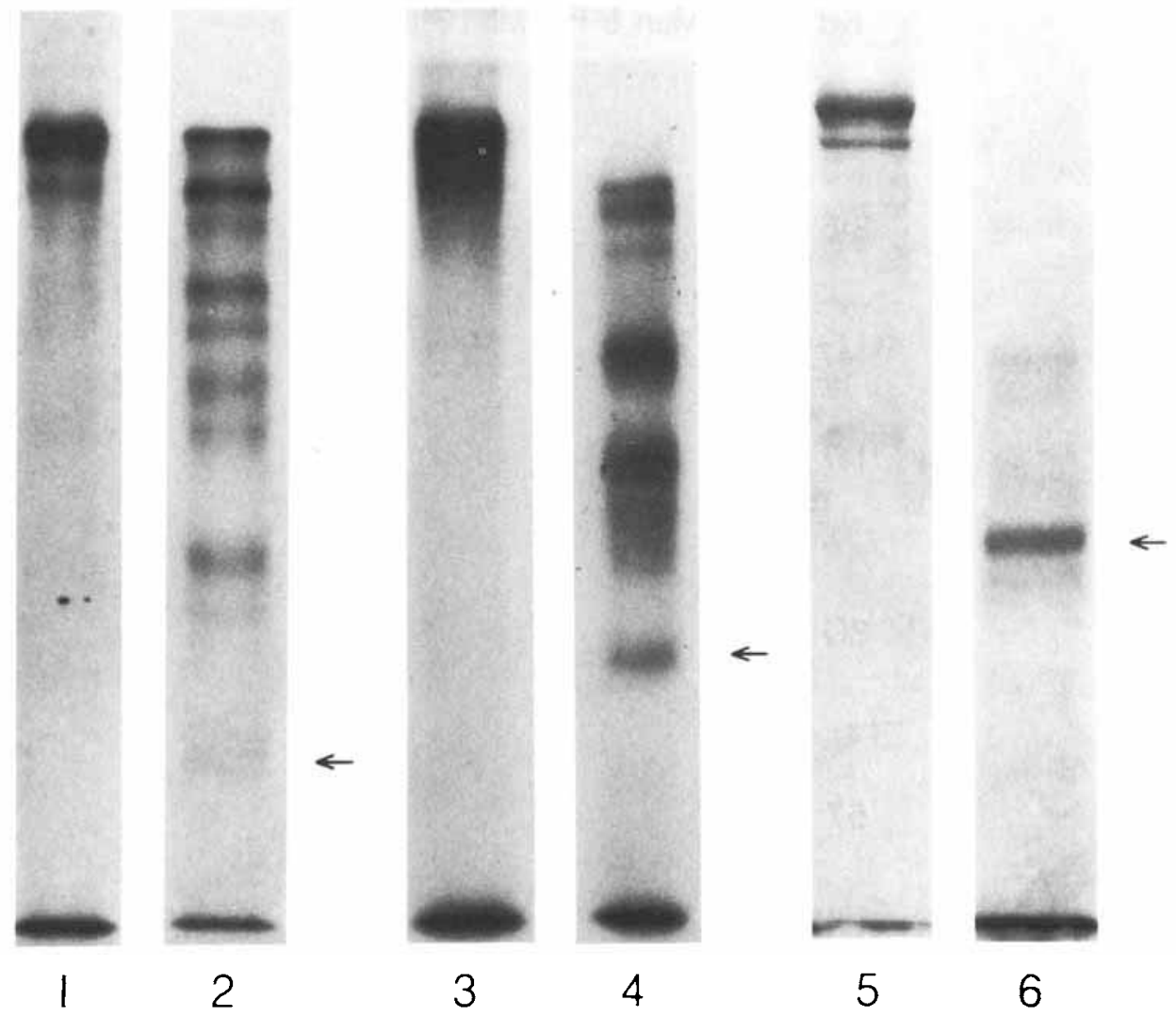

Fig. 4. Dissociation of PMR with time in the presence of Triton X-100 or Zwittergent. Aliquots of PMR or ${ }^{125}$ I-PMR were stored at $4{ }^{\circ} \mathrm{C}$ in either $0.05 \%$ Triton X-100 or $0.04 \%$ Zwittergent in citratephosphate, pH 6.2, containing $0.15 \mathrm{M} \mathrm{NaCl}, 5 \mathrm{mM}$ Man 6-P, and $0.02 \%$ sodium azide. At the times indicated below, aliquots of each mixture were subjected to SDS-PAGE. ${ }^{125}$ I-Labeled compounds were detected by autoradiography and unlabeled compounds by staining with Coomassie blue. Lanes 1 and 2 (7.5\% gel) show autoradiograms of ${ }^{125}$ I-PMR stored for 14 days in Triton $X-100$ or Zwittergent, respectively. Lanes 2 and 3 (9\% gel) show autoradiograms of ${ }^{125}$ I-PMR stored for 28 days in Triton $X$ 100 or Zwittergent, respectively. Lanes 5 and 6 (10\% gel stained with Coomassie blue) show the effect of incubation of PMR at $4^{\circ} \mathrm{C}$ in Triton X-100 for 180 days, and for 56 days in Zwittergent, respectively. The arrows indicate the region on the gels corresponding to a $M_{\mathrm{r}}$ of $57 \mathrm{Kd}$.

\section{Binding Studies}

A Zwittergent-dissociated PMR preparation devoid of material migrating with an apparent $M_{\mathrm{r}}$ of $215 \mathrm{Kd}$ and composed largely of material with an apparent $M_{\mathrm{r}}$ of $57 \mathrm{Kd}$ (see Fig. 4, lane 6), was examined for its ability to bind $\beta$-galactosidase using a previously described binding assay [3]. Low levels of enzyme were bound to the Zwittergent-dissociated PMR (Fig. 6, lower curve). When the Zwittergent in the preparation was removed by dialysis against buffer containing Triton $\mathrm{X}-100$, binding was enhanced approximately threefold (Fig. 6, middle curve) and approximated $48 \%$ of the binding capacity obtained with an equivalent concentration of undissociated PMR prepared in Triton X-100 (Fig. 6, top curve). Whether removal of the Zwitter- 


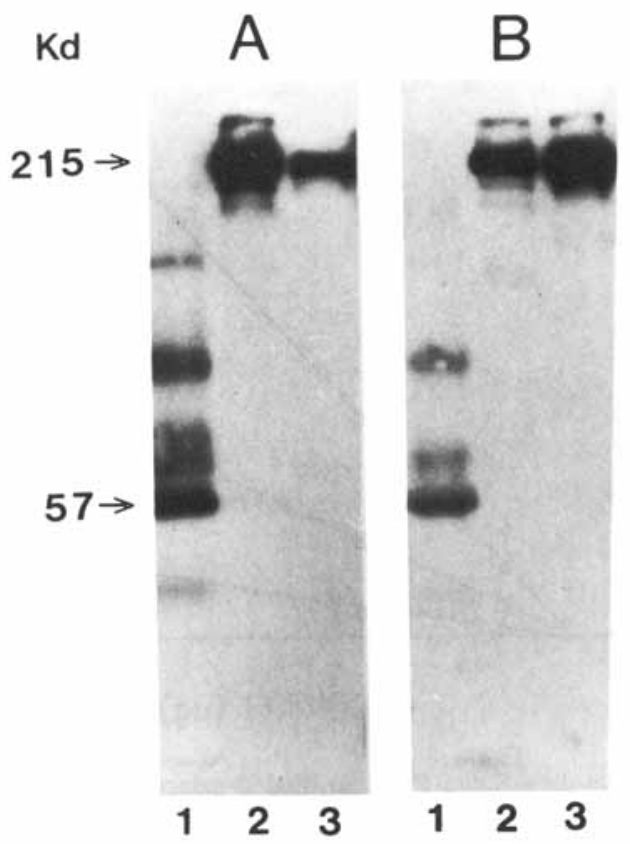

Fig. 5. Demonstration of PMR and PMR subunits by immunoblotting. PMR was treated at $4^{\circ} \mathrm{C}$ for 28 days in Triton X-100 or Zwittergent as described in Figure 4 and subjected to SDS-PAGE on a $7.5 \%$ gel under nonreducing conditions. The protein bands were transferred to nitrocellulose paper and visualized by an immunoblotting procedure [19]. Rabbit antisenum against bovine PMR (A) and rabbit antiserum against affinity purified PMR (obtained from Syrian hamster liver, which was further purified by SDSPAGE) (B) was allowed to react with the electroblotted protein bands. The protein-antibody complexes were reacted with ${ }^{125}$ I-labeled protein $A$ and visualized by autoradiography. Lane 1 contained Zwittergent-dissociated bovine PMR; lane 2 contained bovine PMR; and lane 3, hamster PMR. The latter preparations were stored in Triton X-100.

Table II. Proteinase Activity in PMR Preparations

\begin{tabular}{|c|c|c|c|c|c|}
\hline \multirow[b]{2}{*}{ Storage time } & \multirow[b]{2}{*}{ Storage mixture $\mathrm{e}^{\mathrm{a}}$} & \multicolumn{4}{|c|}{$\begin{array}{c}\text { Percent }{ }^{14} \mathrm{C} \text {-methyl methemoglobin in TCA } \\
\text { supernatant }{ }^{b}\end{array}$} \\
\hline & & $\mathrm{pH} 4.5$ & $\mathrm{pH} 6.2$ & $\mathrm{pH} 6.2^{\mathrm{c}}$ & $\mathrm{pH} 7.9$ \\
\hline 8 months & Triton X-100, complete & 31.5 & 25.2 & - & 29.6 \\
\hline 15 months & Triton $X-100$, complete & 15.5 & 3.4 & 6.3 & 5.0 \\
\hline 6 months & Triton X-100, no Man 6-P & 61.5 & $50.3(57.3)^{d}$ & 63.5 & 52.2 \\
\hline 2 months & Zwittergent, complete & 2.3 & 11.4 & 7.9 & 1.5 \\
\hline
\end{tabular}

${ }^{\mathrm{a}}$ The complete mixture contained citrate-phosphate buffer, $\mathrm{pH} 6.2 ; 0.15 \mathrm{M} \mathrm{NaCl} ; 5 \mathrm{mM}$ Man 6-P; $0.02 \%$ sodium azide; and either $0.05 \%(\mathrm{v} / \mathrm{v})$ Triton $\mathrm{X}-100$ or $0.04 \%(\mathrm{w} / \mathrm{v})$ Zwittergent. Proteinase determinations were performed on aliquots dialyzed at $4^{\circ} \mathrm{C}$ for $20 \mathrm{hr}$ against the same mixture but containing citrate-phosphate buffer of the indicated $\mathrm{pH}$.

broteinase activity was determined by the procedure of Williams and Lin [22]. All reaction mixtures were run in duplicate; $10 \mu \mathrm{g}$ of PMR were added to $40,000 \mathrm{dpm}$ of ${ }^{14} \mathrm{C}$-labeled substrate. Incubations were conducted at $37^{\circ} \mathrm{C}$ for $42 \mathrm{hr}$. Controls lacked PMR.

${ }^{c}$ Incubations contained the proteinase inhibitor cocktail described in Methods.

Incubations included $5 \mathrm{mM}$ Man 6-P. 


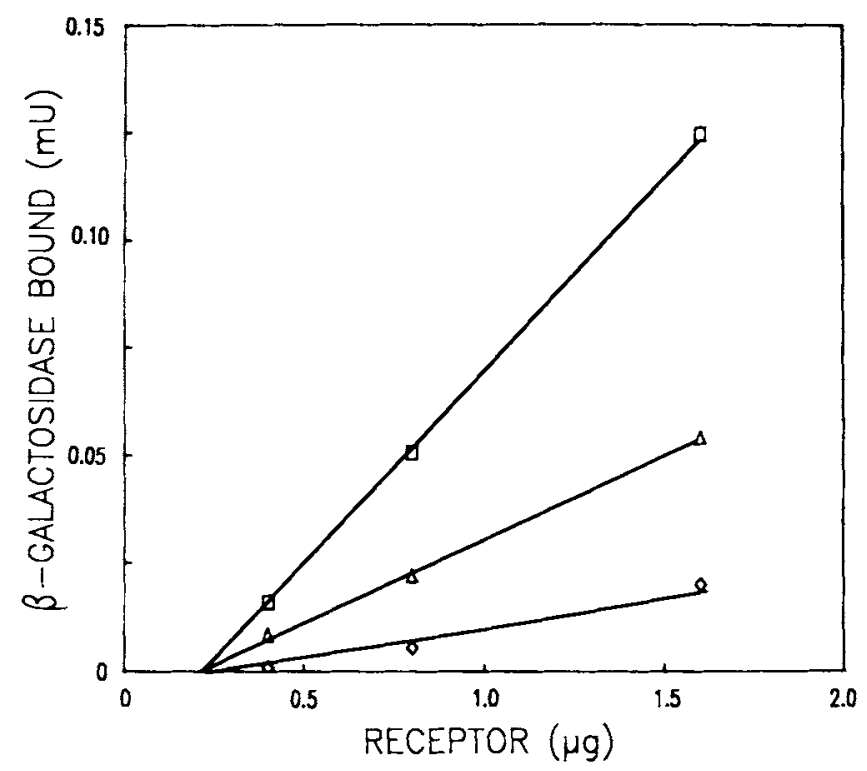

Fig. 6. Ability of Zwittergent-dissociated PMR to bind $\beta$-galactosidase. PMR was either stored in Triton $X-100$ or dissociated with Zwittergent at $4^{\circ} \mathrm{C}$ for 50 days as described in Figure 4 . Aliquots of each preparation were examined for their ability to bind $\beta$-galactosidase with a previously described binding assay [9]. Mannose 6-phosphate $(10 \mathrm{mM})$ was added to separate reaction mixtures; the values obtained were subtracted from those obtained in the absence of Man 6-P. PMR stored in Triton X-100 $(\square-\square)$, Zwittergent-dissociated PMR $(\diamond-\diamond)$, and Zwittergent-dissociated PMR dialyzed against $0.05 \%$ Triton $\mathrm{X}-100$ at $4^{\circ} \mathrm{C}$ for $20 \mathrm{hr}(\triangle-\triangle)$.

gent enhances the ability of subunits of PMR to bind ligand or antibody, or results in reassociation of PMR subunits could not be established. However, binding protein isolated and stored in Triton X-100 bound ligand equally well when assayed immediately in buffer containing Zwittergent [15].

\section{DISCUSSION}

The adsorptive pinocytosis of lysosomal enzymes [3] and the intracellular translocation of newly synthesized lysosomal enzymes is mediated by a specific binding protein called phosphosphomannosyl receptor (PMR) [3]. The binding protein has been isolated from bovine liver [3], swarm rat chondrosarcoma membranes [5], and from rat spleen [10], and has been demonstrated in a number of mammalian tissues and derived cell lines.

This and other laboratories, on the basis of results obtained with SDS-PAGE, have reported that PMR has an apparent $M_{\mathrm{r}}$ of $215 \mathrm{Kd}$. Treatment with SDS or urea does not alter the apparent molecular weight of PMR. However, the observations that (1) PMR extracted from bovine liver membranes with Triton X-100 and stored at $4{ }^{\circ} \mathrm{C}$ for 6 months in the absence of Man 6-P partially dissociated into smaller units, (2) PMR preparations contain multiple $\mathrm{N}$-terminal amino acids, and (3) multiple units of PMR exist in lysosome-enriched preparations from monkey brain [14], suggest that PMR exists as a complex comprising more than one polypeptide chain. This situation is not unique to this binding protein. For example, the insulin receptor [23- 
$25]$ and the asialoglycoprotein receptor [26,27] have been reported to be composed of subunits. While the observed dissociation of PMR was slow, the process was markedly enhanced at acidic $\mathrm{pH}$ values (4.5 to 6.2) in the presence of reducing agent, and Zwittergent.

It can be argued that the apparent dissociation of PMR was the result of the action of contaminating proteinases. Clearly, based on studies with ${ }^{14} \mathrm{C}$-methyl methemoglobin, variable levels of proteinase activity were present in PMR preparations. However, while PMR preparations (containing Triton X-100) exhibited significant levels of proteolytic activity, their ability to bind $\beta$-galactosidase and maintain an undissociated profile remained unchanged. Massague et al have reported that insulin receptor preparations also contain proteolytic activity [28].

Present evidence suggests that a major role for PMR is the intracellular transport of newly synthesized lysosomal hydrolases to lysosomes. The receptor is recycled and reutilized by as yet unknown cellular processes. It is assumed that functional PMR is recycled with the vesicular transport membranes to the cell surface and/or to the Golgi apparatus/GERL region of the cell [1,29-34]. Conceivably, dissociated fragments of PMR could play a role in the recycling process. We have demonstrated recently that the $100,000 \mathrm{~g}$ supernatant from hamster liver extracts contains proteins with apparent $M_{\mathrm{r}}$ values varying between 45 and $57 \mathrm{Kd}$. Each of these proteins react with antiserum against PMR, shown by immunoblots of SDS-PAGE slab gels (Maler and Jourdian, unpublished results). It is tempting to speculate that these proteins are not degraded fragments of large molecular weight PMR $\left(M_{\mathrm{r}}=215 \mathrm{Kd}\right)$ but instead are precursors required for aggregation and formation of functional PMR. Activation, transport, and incorporation of these proteins into the plasma membranes could occur in a fashion analogous to that described for a protein kinase present in embryonic chick fibroblasts [35].

It is clear from the results of the present studies, that concomitant with changes in the $M_{\mathrm{r}}$ profile of PMR stored in Zwittergent, distinct changes occur in the ability of PMR to bind ligand. In addition, distinct changes are also noted in the $M_{\mathrm{r}}$ profile when PMR is incubated at acidic $\mathrm{pH}$ values ( $\mathrm{pH} 4.5-6.2)$. Similar conditions exist in vivo and may promote the changes observed in vitro. Functional PMR has been demonstrated in the interior of clathrin-coated vesicles [36] and in receptosomes [37]. These vesicles and lysosomes have an acid milieu $(\mathrm{pH}<6$ ) maintained by a membrane-associated ATP-driven proton pump [38-40]. On the basis of the results of the present studies, it is tempting to speculate that the acid milieu, in addition to catalyzing dissociation of ligand from receptor [3], may also catalyze at least partial dissociation of the receptor with a concomitant loss in ability to bind ligand. The subunits released could diffuse into the cytosol and the vesicular membranes, devoid of functional receptor, could recycle to the cell surface (or appropriate intracellular compartment), where the receptor could be reconstituted and activated. The time required for the dissociation of the receptor in vitro is obviously too slow to account for the occurrence of a similar process in vivo, where among other factors the concentration of PMR would be lower and its orientation in a membrane would differ from that of the isolated membrane proteins.

\section{ACKNOWLEDGMENTS}

$\mathrm{N}$-Terminal amino acid analyses were performed by G. Tarr, Department Biochemistry, University of Michigan. Amino acid analyses were kindly performed 


\section{0:JCB Mitchell, Maler, and Jourdian}

by D. Dziewiatkowski, Department of Oral Biology, University of Michigan. The authors would like to thank J.J. Distler for his critical comments and Ms. Linda Allen for her assistance in the preparation of the manuscript.

This work was supported in part by grant AM 10531 from the National Institutes of Arthritis, Diabetes, Digestive, and Kidney Diseases and the Arthritis Foundation, Michigan Chapter. Diane C. Mitchell was supported by a grant from the North Atlantic Treaty Organization Science Fellowship Scheme; and Thomas Maler, by the Canadian Cystic Fibrosis Foundation.

\section{REFERENCES}

1. Rome LH, Weissman B, Neufeld E: Proc Natl Acad Sci USA 76:2628, 1979.

2. Gonzalez-Noriega A, Grubb JH, Talkad V, Sly WS: J Cell Biol 85:839, 1980.

3. Sahagian GG, Distler J, Jourdian GW: Proc Natl Acad Sci USA 78:4829, 1981.

4. Robbins AR, Myerowitz R: I Biol Chem 256:10623, 1981.

5. Steiner AW, Rome LH: Arch Biochem Biophys 214:681, 1982.

6. Hasilik A, Voss B, von Figura K: Exp Cell Res 133:23, 1981.

7. Gabel CA, Goldberg DE, Kornfeld S: Proc Natl Acad Sci USA 80:775, 1983.

8. Fischer HD, Gonzalez-Noriega A, Sly WS, Morre DJ: J Biol Chem 255:9608, 1980.

9. Sahagian GG, Distler JJ, Jourdian GW: Methods Enzymol 83:392, 1982.

10. Sly WS, Fischer HD: J Cell Biochem 18:67, 1982.

11. Fischer HD, Creek KE, Sly WS: J Biol Chem 257:9938, 1982.

12. Varki A, Kornfeld S: J Biol Chem 258:2808, 1983.

13. Brown MS, Anderson RGW, Goldstein JL: Cell 32:663, 1983.

14. Alvares K, Balasubramanian AS: Biochem Biophys Res Communs 112:398, 1983.

15. Mitchell DC, Sahagian GG, Distler JJ, Wagner RM, Jourdian GW: Methods Enzymol 98 (Part L):304, 1983, (in press).

16. Lowry OH, Rosebrough NJ, Farr AL, Randall RJ: J Biol Chem 193:265, 1951

17. Laemmli UK: Nature 227:680, 1970.

18. Sammons DW, Adams LD, Nishizawa EE: Electrophoresis 2:135, 1981

19. Howe JG, Hershey WB: J Biol Chem 256:12836, 1981.

20. Tarr GE: In Elizinga M (ed): "Methods in Protein Sequence Analysis." Clifton, New Jersey: Humana Press Inc., 1982, pp 223-232.

21. Moore S, Stein WH: Methods Enzymol 6:819, 1963.

22. Williams HR, Lin T-Y: Biochim Biophys Acta 250:603, 1971.

23. Czech M: Cell $31: 8,1982$.

24. Kasuga M, Zick Y, Blith DL, Karlsson FA, Härring HU, Kahn CR: J Biol Chern 257:9891, 1982.

25. Petruzzelli LM, Ganguly S, Smith CJ, Cobb MH, Rubin CS, Rosen OM: Proc Natl Acad Sci USA 79:6792, 1982.

26. Steer CJ, Kempner ES, Ashwell GA: J Biol Chem 256:5851, 1981.

27. Harford J, Lowe M, Tsunoo H, Ashwell G: J Biol Chem 257:12685, 1982.

28. Massague J, Pilch PF, Czech MP: J Biol Chem 256:3182, 1981.

29. Willingham MC, Pastan IH, Sahagian GG, Jourdian GW, Neufeld EF: Proc Natl Acad Sci USA 78:6967, 1981.

30. Willingham MC, Pastan IH, Sahagian GG: J Histochem Cytochem 31:1, 1983.

31. Merion M, Sly WS: J Cell Biol 96:644, 1983.

32. Neufeld EF, Ashwell G: In Lennarz WJ (ed): "The Biochemistry of Glycoproteins and Proteoglycans." New York: Plenum Press, 1980, pp 241-266.

33. Stahl PD, Schlesinger PH: Trends Biochem Sci 5:194, 1980.

34. Farquhar MG: Fed Proc 72:2407, 1983.

35. Courtneidge SA, Bishop JM: Proc Natl Acad Sci USA 79:7117, 1982.

36. Campbell CH, Fine RE, Squicciarini J, Rome LH: J Biol Chem 258:2628, 1983.

37. Dickson RB, Bequinot L, Hanover JA, Richert ND, Willingham MC, Paxton I: Proc Natl Acad Sci USA $80: 5335,1983$

38. Schneider DL: J Biol Chem 256:3858, 1981.

39. Stone DK, Xie X-S, Racker E: J Biol Chem 258:4059, 1983.

40. Reijngoud DJ, Tager JM: Biochim Biophys Acta 472:419, 1977. 